\title{
Ethical Aspects of Translation: Striking a Balance between Following Translation Ethics and Producing a TT for Serving a Specific Purpose
}

\author{
Rafat Y. Alwazna ${ }^{1}$ \\ ${ }^{1}$ Department of European Languages and Literature, King Abdulaziz University, Jeddah, Saudi Arabia \\ Correspondence: Rafat Y. Alwazna, P.O. Box 14354, Jeddah 214424, Saudi Arabia, Mobile: 966-504-510-911, \\ E-mail: alwazna@gmail.com \\ Received: May 5, 2014 \\ Accepted: May 21, 2014 \\ Online Published: May 22, 2014 \\ doi:10.5430/elr.v3n1p51 \\ URL: http://dx.doi.org/10.5430/elr.v3n1p51
}

\begin{abstract}
Translation ethics have been strictly defined as the practice to keep the meaning of the source text undistorted (Robinson, 2003, 25). Obviously, this notion of translation ethics is too restricted as the translator in specific cases is required to distort parts of meaning of the original text to live up to the audience expectations (Robinson, 2003, 26). Two opposing views of scholars with regard to translation ethics can clearly be identified. The first view is represented by Humboldt, for instance, who insists on the need for keeping the foreign elements found in the original text intact in the target text. Schleiermacher calls the translator to enable the target reader to hear the voice of the original writer, rather than the voices of any other party. Berman's method for preserving translation ethics is to advocate literal translation in order to respect the source text's form and content (Hermans, 2009, 97-98). The second view is held by Nord (1997) in his 'functionalist studies', which raise particular questions, such as what purpose the target text is meant to serve in the target culture and who is responsible for commissioning the translation. The present paper will argue that the translator should strike a balance between following ethical aspects of translation, especially those related to the transfer of form and content of the source text into the target language and producing a target text that can fulfil in the target language the appropriate function for which it has been produced.
\end{abstract}

Keywords: Translation ethics, Translation norms, Source text, Translation ideology, Form, Content

\section{Introduction}

Currently, the majority of professions possess a particular code of ethics. These ethics have developed as a result of people's realisation concerning the importance of showing what is acceptable within a particular profession and what is not (Phelan, 2001, 39). Translation as a well-known and well-established profession and as an enjoyable activity, if recognised as a pivotal element within cultural systems (Tymoczko, 2006, 443), has also a specific code of ethics. Indeed, translation in itself is regarded as an ethical activity (Goodwin, 2010; Baker \& Maier, 2011). It can be viewed as an activity with a set of ethics, ideology and politics, rather than a linguistic activity (Tymoczko, 2006, 443). Indeed, translation is driven by ethics. It plays a significant role in shaping societies and nations in different ways such that translation can make pivotal changes on the globalised world (Tymoczko, 2006, 459). Moreover, professional translators have started to show particular interest in translation ethics, which emanates from their belief that they have become influential figures in the movements of human rights that mark today's world (Baker \& Maier, 2011, 1).

This paper addresses the concept of how a balance can possibly be struck between respecting and following translation ethics and producing a target text that fits the cultural setting of the target language and serves its purpose. It is indeed a consequence of continuous independent research conducted with regard to the concept of translation ethics and how it is viewed and interpreted in different ways. Particular emphasis has been given to the concept of translation ethics in its narrow sense, which primarily lies in following the form and content of the source text as much as possible in producing the target text in the target language and culture. Specific academic works have been carefully chosen in order to be cited in the paper concerned. These academic works have been chosen for citation on the basis of their academic accreditation in the field of translation studies, particularly within the context of translation ethics.

The paper starts by providing a definition of translation ethics, with some elaboration on the concept of translation and how it can be adapted to suit different contexts and readership. Different studies and views on the concept of 
translation are then presented, with a relatively succinct discussion of each study and view, in an attempt to show how the concept of translation is seen and understood by translation scholars and translators differently and the apparent change that has taken place with regard to viewing the concept of translation through time periods. A complete section is devoted to deal with translation norms and translation ethics, showing that the relation between them may reside in the positive reaction of the translator to a specific translation situation. However, if translation ethics are interpreted by following the source text and reproducing its form and content as much as possible, the main theme of the present paper, some contradiction between translation norms and translation ethics may emerge. The paper presents two broadly opposing views with regard to translation ethics. At one end of the continuum, there are translation scholars who hold the view that translators should respect translation ethics by adhering to the form and content of the source text and reproducing them as much as possible in the target language regardless of whether or not the target text sounds foreign to the target reader. At the other end of the continuum, there are other translation scholars who claim that translators should endeavour to produce a target text that lives up to the expectations of the target reader, runs in line with the cultural norms of the target language and serves its appropriate purpose. The present paper would argue for a place between such two ends, respecting translation ethics by following the source text's form and content as much as possible, and producing a target text which is understandable by the target reader and fulfils its function.

\section{Definition and Concept}

Benjamin (1999) states "instead of resembling the meaning of the original, must lovingly and in detail incorporate the original's mode of signification, thus making both the original and the translation recognizable as fragments of a greater language, just as fragments are part of a vessel" (p. 79).

Translation ethics have been strictly defined as the practice to keep the meaning of the source text undistorted (Robinson, 2003, 25). Obviously, this notion of translation ethics is too restricted as the translator in specific cases is expressly required to distort the meaning of the original text to live up to the audience expectations, such as adapting the target text for children's story, television, advertising campaign, etc (Robinson, 2003, 26; Icoz, 2012, 131). This runs in line with Tymoczko $(2006,448)$, who asserts that new investigations in the field of translation studies confirm that translation can be adapted to suit different contexts, readership, media, technology, etc.

Broadly, ethics arguably rest on the notion of how some one should behave, and it addresses epistemology; how some one knows what kind of matter a particular thing belongs to (Eaglestone, 2005, 136). In translation, responsibility lies in the concept that is not comprehended by the translator (Eaglestone, 2005, 137). Therefore, it is claimed that the translator should endeavour to comprehend even the author's presuppositions (Spivak, 2005, 93).

\section{Different Studies and Views on the concept of translation}

Translation can be viewed as "the most intimate act of reading" (Spivak, 2005, 94). According to Western culture, translation has been seen as a communicative and intercultural process of transfer in which content is conveyed from one language into another (Tymoczko, 2006, 443). However, translation studies have recently shown shift in interest of translation from being only an intercultural communication to the inquiry about intercultural functions of translation processes and products. Such approaches have existed within the realm of translation ethics, politics and ideology (Tymoczko, 2006, 445).

The point lies mainly in how a balance can possibly be struck between traditional translation, which usually draws on literalism and hardly examines the quality of the target text, and the functionalist studies (Nord, 1997), which raise particular queries, such as what purpose the target text is meant to serve in the target culture and who is responsible for commissioning the translation (Hermans, 2009, 94). Along similar lines and within descriptive paradigm, Lefevere (1992) goes on to explore the impact of translation within ideological, cultural and social settings. He argues that the validity of translation is determined by ideology, then poetics. The language occupies the third spot in determining the translation, according to his views. Following this path, Lefevere examines the textual, generic and ideological grids, which founded $19^{\text {th }}$ century Virgil's English translations (Hermans, 2009, 95). Indeed descriptive studies continue to cover a wide range of different practices within translation process; from choosing a particular text for translation, to adopting a specific translation strategy, to publishing the target text, along with a particular ideology. Such descriptive studies have managed to underscore how various translations are founded on the politics of specific spaces and particular time periods (Tymoczko, 2010, 225).

It can be claimed that both functionalism together with descriptivism are particularly concerned with questions, such as: who translates the text, what is the text that needs translation, to whom is it directed, when is it translated, why is it translated, where is it translated and how is it translated? Professional translators usually encounter particular areas 
in their work in which they have to make important decisions with regard to the style adopted in their translation, which includes sentence structure and the use of lexical items, alongside the issue of whether or not they should accept a commission (Hermans, 2009, 95).

Other studies continue to go further, showing, for instance, how translation from Greek and Latin in Victorian Britain contributed successfully to the concept of a national culture (Osborne, 2001; Prins, 2005; Hermans, 2009). Following the same theme, the collection edited by Bassnett and Lefevere (1990) Translation, history and culture, gives credence to the notion that translation was noticeably approached from the cultural perspective. It is argued that the translation produced for a particular audience, i.e. the target text per se is deemed a fact pertaining to a single language, a single textual tradition, and therefore it is related to the target culture (Toury, 1980, 82-83; Tymoczko, 2010, 216). Hence, translators are regarded as 'persons-in-the-culture' of the TL system (Toury, 1995, 40; Tymoczko, 2010, 216). Though this argument can be challenged, it remains an important claim arising from the evolution of translation studies (Tymoczko, 2010, 216).

In his essay, Simms (1983) explains how the position of the translator intersects with the translation politics. He goes on to confirm the aforementioned proposition in both cases whether the translator belongs to the postcolonial culture, supporting the imperial language through translating into this language and its culture, or whether he/she takes one of the potential positions in which translation takes place targeting members of the TL culture in a particular system. Theoretical claims and descriptive studies carried out by a number of scholars, including Simms, show that the place of the translator can be taken within the TL culture, SL culture or in a different culture, as in the case when German philologists rendered some literature written originally in Irish into English, then published it in series written in German (Tymoczko, 2010, 217).

The translator's ideological position and temporal position are both deemed pivotal issues related to the evolution of translation studies. This indeed has led to the notion of viewing translation as a space or place separated from the real and cultural position held by the translator, and different from the translator's ideological position too (Tymoczko, 2010, 217). Researched and utilized as a fruitful subject tackled by writers engaged in translation theory and practice, translation has been viewed as a space located between different spaces (Tymoczko, 2010, 217). Within the same line of thought, Simon $(1996,162)$ views translation as 'the blurred edge' in which the source text and the target text may meet. This space is difficult to the extent that no writer can hold it. She then sees the domain of translation as the reach of a person with multicultural backgrounds; it is the hybrid place which exists between the realities of different national cultures, though has no role to play in affecting any of them (Simon, 1996, 153). Indeed, Simon (1996) follows in her methodology Spivak (1992), the work of whom has been regarded as one of the most momentous exploration within the notion of translation ideology.

Spivak $(1992,178)$ views translation as a kind of activity in which meaning moves from one place to another and stabilizes in a particular space between the source and target languages. This is given credence by Mehrez (1992, 121), within the translation and postcolonial context, who claims that texts produced by postcolonial bilingual writers create a language, which is characterized by being placed in a specific space 'in between', i.e. between the source and target languages. Tymoczko $(2010,219)$ explains the main reason behind viewing translation as a space between two languages, claiming that due to the physical positioning of the translator as being a speaker located between two different communities, it has become logical to consider translation a space between two different languages. However, from the perspective of translation ideology, the notion of considering translation a space 'in between' is deemed problematic as it leads to misconception of the nature of engagement itself, though translation demands collaboration and affiliation (Tymoczko, 2010, 226).

\section{Translation Norms and Ethics}

Translation norms may serve as a helpful tool for translators. Their nature can be interpreted from both social as well as psychological perspectives. From a social side, norms are said to live up to societies' expectations and respect their values and traditions (Hermans, 2009, 95). Within such social systems, translation serves as an invisible means of cultural appropriateness, seeking to establish identities and affiliations (Tymoczko, 2006, 446). On the other hand, norms are psychological in that they comprise a set of shared and common expectations with regard to the individuals' behaviours and the decisions they have to make in a particular situation (Hermans, 2009, 95). Toury (1995), who has taken on board the concept of translation norms, views them as restrictions, which determine the translator's behaviour. He confirms that decisions taken by the translator, which shape the final draft of his/her translated text are primarily based and determined by norms. In other words, Toury sees norms as guidance to the translator with regard to word choice, and consequently, they play a substantial role in formulating the resulting 
target text. Other scholars, such as Hermans (1991), Geest (1992) and Nord (1997) enhance the theoretical foundation of norms by presenting the mutual impacts on both the translator and audience.

Norms can particularly be viewed as problem-solving tools that scaffold translators to perform their translation tasks within social and cultural criteria. In that, they enable translators to be aware of the socially acceptable statements, which results in producing a translation deemed by the audience a legitimate and valid target text (Hermans, 2009, 96).

Chesterman (1997a, 1997b) associates norms with translation ethics, arguing that translation ethics require strict commitment to precise expressions, production of a truthfully equivalent target text, building trust between translators and clients or any other parties involved in this transaction as well as the reduction of possible misunderstanding between the parties involved in the transaction. Based on ethical codes of conduct followed in well-known and professional organizations, Chesterman (2001) goes on to suggest that all translators and interpreters worldwide should make an oath similar to the model used in medical profession. This is lent credence by Pym (2001), who emphasizes the concept that ethics are particularly related to the reaction of individuals in a particular concrete situation, then comes the importance of abstract fundamentals.

Pym $(1992,2002,2004)$ addresses the issue of ethical aspects of translation in detail. He claims that since translation is broadly viewed as a cross-cultural transaction, one important role that should be played by the translator is to secure cooperation between all parties involved in this transaction, seeking to achieve mutual benefit that can be derived by all parties concerned. Pym places emphasis on professional translators, viewing them as acting within intercultural space, which is the proper place for the skilful cultural mediator who is able to establish efficient interlingual and intercultural communication. These professional and intercultural mediators follow important ethical aspects, which go beyond the work of translation to cover other languages facilities. In this respect, Pym, for instance, believes that the cultural mediator may advise the client to learn a particular language if the client will need this language on a continual basis in the long term. This advice unequivocally provides mutual benefit to all parties concerned.

It is argued that translators are not completely restricted by norms; rather they make their own way through these norms so as to have a particular position in the translation process. Doing so, the translators are clearly viewed as restating the source text in a different way (Mossop, 1983; Hermans, 2009). This shows that translators intervene in new texts through giving their voices in them, in an attempt to take up a position in the current discourse. Consequently, translation unequivocally involves translator's subjectivity, with a complicated message including diverse and intermingled speaking voices and views (Hermans, 2009, 96-97; Icoz, 2012, 131). Within the same line of thought, Bakhtin $(1981,1986)$ points out that the translator's ideology and position are inevitably found in the target text that he/she has produced. At the same time, questions of accountability and responsibility, which relate to ethics, are also raised by the translator.

Conversely, some translation scholars call for the preservation of the foreignness of the original text in the target text. Humboldt, for instance, insists on the need for keeping the foreign elements found in the original text intact in the target text. Schleiermacher calls the translator to enable the target reader to hear the voice of the original writer, rather than the voices of any other party. Berman's method for preserving translation ethics is to advocate literal translation in order to respect the source text's form and content. Within the English speaking world, Venuti supports Berman's views of ethics, discussing ethics of difference, but adding an ideological and political element thereto (Hermans, 2009, 97-98).

Badiou (2001), in his interpretation of truth-based ethics, argues that truth has nothing to do with adequacy to reality or enlightenment. It is, however, a process of investigation, which deals with an event that presents something different from the current situation, which is identified by "opinions and instituted knowledges" (p. 67). The event is meant to locate and support the lack in the current situation. This gives rise to the creation of a subject whose task is to maintain a break with it through investigating the results of the event, form, the ramifications of the concept along with the practice which possesses such merit so as to be called truth (Venuti, 2013, 184).

Translation ethics can be more complex from the translator's perspective. A number of thorny issues may confront the translator and pose potential problems with regard to how the translator can possibly deal with them. For instance, what should the translator do when required to render a text which is deemed offensive? What should he/she do when professional ethics are repugnant to his/her personal moral ethics? What should the translator do when he/she needs to translate a particular discourse which he/she does not agree with or does not feel comfortable translating it? (Robinson, 2003, 26; Phelan, 2001, 56). Translators and interpreters should always bear in mind that they are not liable for the nature of the message, rather for conveying it adequately and precisely. If they feel uncomfortable 
translating a particular message content into another language, they should withdraw from the situation (Phelan, 2001, 56).

From the client's perspective, the above concerns do not form important issues in translation. The translator is expected to translate what he/she is asked to translate, and he/she is required to translate in such a way that runs in line with the target text's user's satisfaction (Robinson, 2003, 26). The translator, like the interpreter, should not undertake a translation task which he/she cannot accomplish due to any particular reason (Phelan, 2001, 39). The translator has no point of view with regard to the act of translation (Robinson, 2003, 26). This is in line with some translators, who believe that the translator should not do anything that runs contrary to the interest of the translation users; those who are paying for the translation (Robinson, 2003, 26).

By contrast and from a different point of view, translators, as all professionals, want to enjoy their work and would like to feel proud of themselves as translators. Therefore, if their professional ethics are contrary to their own personal ethics to the point that it becomes difficult to feel this kind of pride, they may make momentous decisions with regard to the place and conditions under which they accept to work. Taking this on board, translators are beginning to strike a balance between their own personal ethics and their professional ethics as professional translators (Robinson, 2003, 26). They are required to make particular choices as they can never relay all features of the source text into the receptor language. Thus, their choices would determine their position of enunciation. This gives rise to the notion of establishing priorities in translation (Tymoczko, 2006, 453) as translation loss will inevitably take place in any translation work. The choices made by translators should clearly determine the ST elements that must be rendered into the TL, and those which should be dispensed with, hence translation may arguably be viewed as a metonymic process (Tymoczko, 2006, 453).

Having considered the main theme of the present paper, which primarily resides in how a balance can possibly be struck between respecting professional translation ethics and producing a translation for serving a particular purpose, it seems significant that the translator should fully recognize the importance of three crucial factors on which his/her translation strategy may intrinsically be based. These factors include the nature of the text he/she is required to translate, the purpose of the translation or what Icoz $(2012,132)$ calls 'the aim of the translation' and the type of audience to whom the translation is directed. The translator needs to build his/her strategic decisions upon the aforementioned factors, treating each factor on its own merit. Such strategic decisions should be justifiable as any person might question them (Baker \& Maier, 2011). However, if confronted with a severely offensive texts; having to translate some lines that contain noticeable insults or negative statements against specific religions or particular prophets, which are totally repugnant to the translator's personal ethics, the translator may withdraw from the situation, as stated by Phelan (2001) above.

\section{Concluding Remarks}

Translation, as other well-established and well-known professions, has a specific code of ethics, which should be fully respected by translators. Translation as an important profession and as an enjoyable activity, has been variably viewed by different translation scholars and translators. After translation has long been regarded as an intercultural transfer, other studies have come into being, which inquire about the intercultural functions of translation processes and products. There have also been some investigations about the translator's ideology and its implications on translation. Distinctive studies have positioned translation in a position located between the source language and the target language.

Norms of translation are considered pivotal tools that guide the translator to know what is acceptable in a particular society and what is not, so that the translator can be greatly guided to formulate the final shape of his/her translation. Taken on board the broad sense of translation ethics, there is a clear connection between translation norms and translation ethics, which may well appear in the positive reaction of the translator to a particular translation situation and the act of building trust among all the parties participating in the translation process/transaction. However, translation norms can at times oppose translation ethics, if what is meant by ethics is to follow the source text verbatim, the main theme of the present paper.

In this respect, there are broadly two opposing camps of translation scholars. At one end of the spectrum, there are scholars who believe in following the source text literally regardless of whether or not the target text sounds exotic to the target reader, thus conveying the form and content of the source text into the target language. At the other end of the spectrum, there are other scholars who argue over the merit of producing a target text that lives up to the expectations of the target reader, fits the cultural setting of the target language and fulfils its appropriate function, thus making substantial changes on the source text form and probably the content too. The present paper would argue for a middle place between the two; following translation ethics by reproducing the form and content of the source 
text as much as possible and, at the same time, producing a target text which is comprehensible by the target reader and can fulfil its function. Special emphasis should be placed on the text type, the purpose of the translation and the type of audience. Finally, if the translator fails to strike the right balance between respecting translation ethics and producing a translation that can serve its purpose, or if he/she is faced with a largely offensive text, the translator may withdraw from the situation.

\section{References}

Badiou, A. (2001). Ethics: An essay on the understanding of evil. Trans. P. Hallward. London: Verso.

Baker, M. \& Maier, C. (2011). Ethics in interpreter \& translator training: Critical perspectives. The Interpreter and Translator Trainer, 5(1), 1-14. http://dx.doi.org/10.1080/13556509.2011.10798809

Bakhtin, M. (1981). The dialogic imagination: Four essays. Ed. M. Holquist. Trans, C. Emerson and M. Holquist. Austin/Texas: University of Texas Press.

Bakhtin, M. (1986). Speech genres and other late essays. Trans V. W. McGee. Austin/Texas: University of Texas Press.

Bassnett, S. \& Lefevere, A. (eds.), (1990). Translation, history and culture. London/New York: Pinter.

Benjamin, W. (1999). Illuminations. London: Pimlico.

Chesterman, A. (1997a). Memes of translation: The spread of ideas in translation theory. Amsterdam/Philadelphia: John Benjamins. http://dx.doi.org/10.1075/btl.22

Chesterman, A. (1997b). Ethics of translation. In M. Snell-Hornby, Z. Jettmarova \& K. Kaindl (eds.), Translation as intercultural communication: Selected papers from the EST Congress, Prague 1995. (pp. 147-157). Amsterdam/Philadelphia: John Benjamins.

Chesterman, A. (2001). Proposal for a Hieronymic oath. The Translator, 7, 139-154. http://dx.doi.org/10.1080/13556509.2001.10799097

Eaglestone, R. (2005). Levinas, translation, and ethics. In S. Bermann \& M. Wood (Eds.), Nation, language and the ethics of translation. (pp. 127-138). Princeton, NJ: Princeton University Press.

Geest, D. (1992). The notion of system: Its theoretical importance and its methodological implications for a functionalist translation theory. In H. Kittel (ed.), Geschichte, system, literarische ubersetzung. [Histories, systems literary translations.] (pp. 32-45). Berlin: Erich Schmidt.

Goodwin, P. (2010). Ethical problems in translation: Why we might need Steiner after all. The Translator, 16(1), 19-42. http://dx.doi.org/10.1080/13556509.2010.10799292

Hermans, T. (1991). Translational norms and correct translations. In K. Ban Leuben-Zwart \& T. Naaijkens (eds.), Translation studies: The state of the art-proceedings of the first James S. Holmes Symposium on translation studies. (pp. 155-169). Amsterdam: Rodopi.

Hermans, T. (2009). Translation, ethics, politics. In J. Munday (ed.), The routledge companion to translation studies. (pp. 93-105). London: Routledge.

Icoz, N. (2012). Considering ethics in translation. Electronic Journal of Vocational Colleges, 2(2), 131-134.

Lefevere, A. (1992). Translation, rewriting and the manipulation of literary fame. London/New York: Routledge.

Mehrez, S. (1992). Translation and the postcolonial experience: The Francophone North African text. In L. Venuti (ed.), Rethinking translation: Discourse, subjectivity, ideology. (pp. 120-138). London: Routledge.

Mossop, B. (1983). The translator as rapporteur: A Concept for training and self-improvement. Meta, 28(3) 244-278. http://dx.doi.org/10.7202/003674ar

Nord, C. (1997). Translating as a purposeful activity: Functionalist approaches explained. Manchester: St Jerome.

Osborne, H. (2001). Hooked on classics: Discourses of allusion in the mid-Victorian novel. In R. Ellis and L. Oakley-Brown (eds.), Translation and nation: Towards a cultural politics of Englishness. (pp. 120-166). Clevedon: Multilingual Matters.

Phelan, M. (2001). The interpreter's resource. Clevedon: Multilingual Matters. 
Prins, Y. (2005). Metrical translation: Nineteenth century homers and the hexameter mania. In S. Bermann \& M. Wood (Eds.), Nation, language and the ethics of translation. (pp. 229-256). Princeton-NJ: Princeton University Press.

Pym, A. (1992). Translation and text transfer: An essay on the principles of intercultural communication. Frankfurt am Main/Berlin/Bern: Peter Lang.

Pym, A. (2001). Introduction: The return to ethics in translation studies. The Translator, Special Issue The Return to Ethics, 7(2), 129-138.

Pym, A. (2002). On cooperation. In M. Olohan (ed.), Intercultural faultlines: Research methods in translation studies I: Textual and cognitive aspects. (pp. 181-192). Manchester: St. Jerome.

Pym, A. (2004). Propositions on cross-cultural communication and translation. Target, 16(1), 1-28. http://dx.doi.org/10.1075/target.16.1.02pym

Robinson, D. (2003). Becoming a translator: An introduction to the theory and practice of translation. $2^{\text {nd }}$ ed. London: Routledge.

Simms, N. (1983). Three types of 'Touchy' translation. Pacific Quarterly Moana, 8(2), 48-58.

Simon, S. (1996). Gender in translation. London/New York: Routledge. http://dx.doi.org/10.4324/9780203202890

Spivak, G. C. (1992). The politics of translation. In M. Barrett \& A. Phillips (eds.), Destabilizing Theory. (pp. 177-200). Oxford: Polity Press.

Spivak, G. C. (2005). Translating into English. In S. Bermann \& M. Wood (Eds.), Nation, language and the ethics of translation. (pp. 93-110). Princeton, NJ: Princeton University Press.

Toury, G. (1980). In search of a theory of translation. Telaviv: Porter Institute.

Toury, G. (1995). Descriptive translation studies and beyond. Amsterdam/Philadelphia: John Benjamins.

Tymoczko, M. (2006). Translation: Ethics, ideology, action. The Massachusetts Review, 47(3), 442-461.

Tymoczko, M. (2010). Ideology and the position of the translator: In what sense is a translator 'In Between'. In M. Baker (ed.), Critical readings in translation studies. (pp. 213-228). Oxon: Routledge.

Venuti, L. (2013). Translation changes everything: Theory and practice. Oxon/New York: Routledge. 